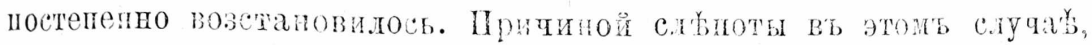
каке показалт обтальноскопт, била neuro-retinitis acuta abuminurica.

H. Kazyurumo.

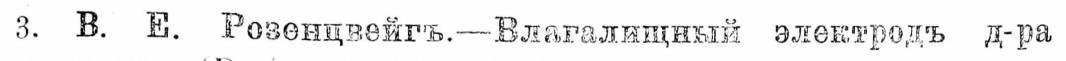

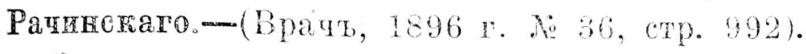

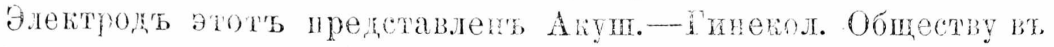

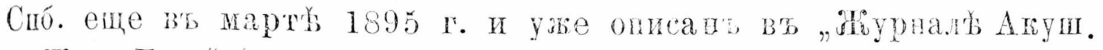
и жен. Бол." (1895 г. (тү). 404). Авторь настолпей статьи цово-

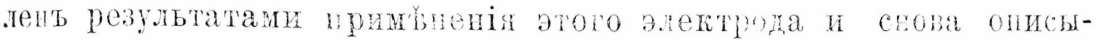

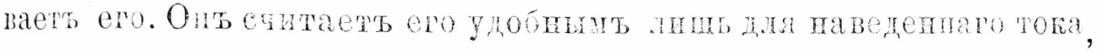
H. Taкуиминг.

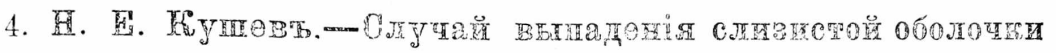

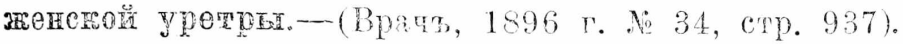

Чаще всего это страданіе наблюдаесл у дытей и стапухь при общей слабости, истопеніи, также прп долом существовапии

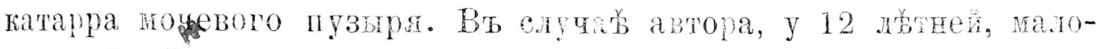

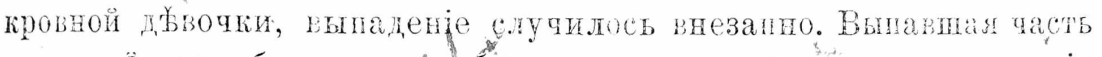
с'ь китайское яблоко, сь "небольиины перехватом' у осповадія nоверхность опухоли нрасноватал, покрытая тривно стрыны нале-

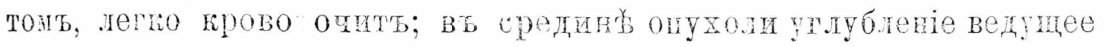

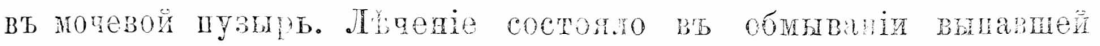
части $2 \%$ борным раствороль и вт слазиваніи таннино глицериномь. Больная иотравллась.

H. Какуикин.

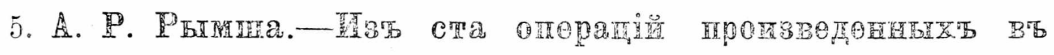

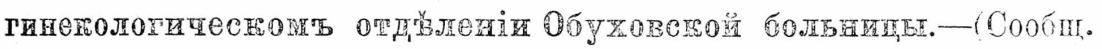
Проток. Засъданій Сиб. Мец. Общ. за 1895 г. Спо. 1896, стр. 38).

Кратко описаны пать иревоспиеній, проивведенныхь по поводу кожевика яичника (2 случая), жногополостной кисть яичника (1 случай) и внекматочной (трубиой) беременности (2 случая). Вь

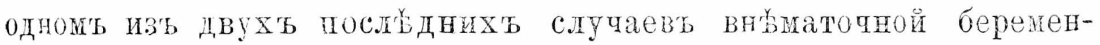
ности имела масто и двухифсячная маточиая беремениость, огончившаяся на 11 сутки шосль операпіи выкидыемғ; в' этонь

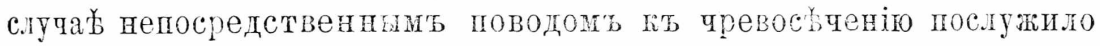
внугреннее провотеченіе, вельдствіе разрыва трубы. Вь этой-же стать' оцисаны три случая влагалищнаго удаленія матки, два по поводу рака шейки и одины по поводу саркомы матки. Веґ описанные въ стать со случаи окончились выздоровленіешь

\title{
H. Какуикинг,
}

